\title{
Bacillus thermoruber sp. nov., nom. rev., a Red-Pigmented Thermophilic Bacterium
}

\author{
P. L. MANACHINI, ${ }^{*}$ M. G. FORTINA, C. PARINI, AND R. CRAVERI \\ Istituto di Microbiologia Agraria e Tecnica, Università degli Studi di Milano, 20133 Milano, Italy
}

\begin{abstract}
The morphological, cultural, and physiological properties of a new species of Bacillus are reviewed. This microorganism, for which we propose the name Bacillus thermoruber, is motile, produces terminal or subterminal oval endospores in swollen sporangia, and shows optimal growth at 45 to $48^{\circ} \mathrm{C}$. It is characterized by a high deoxyribonucleic acid guanine-plus-cytosine content $(57 \pm 0.8 \mathrm{~mol} \%)$ and a red, endocellular, nondiffusible pigment. The type strain is strain BT2, which has been deposited in the collection of the Cattedra di Microbiologia Industriale, Università degli Studi di Milano (Italy) as strain MIM 30.8.38.
\end{abstract}

In the course of a study on thermophilic microfloras of the compost used for the production of mushrooms (Agaricus campestris var. bispora), we isolated a rod-shaped, sporeforming, aerobic, thermophilic bacterium belonging to the genus Bacillus. This microorganism produced a characteristic red, nondiffusible pigment. According to its morphological, cultural, and physiological properties, this strain could not be identified as a member of any species described previously. Therefore, we believe that this bacterium represents a new species of the genus Bacillus $(2,10)$.

Although this species has been described previously (2, 10 ) as "Bacillus thermoruber," this name did not appear on the Approved Lists of Bacterial Names (22). Therefore, a formal description which includes new data to support designation of a new species is given in this paper.

\section{MATERIALS AND METHODS}

Microorganism. Strain BT2 ${ }^{\mathrm{T}}$ ( $\mathrm{T}=$ type strain) was grown on TER $/ 1$ agar slants (4) and was maintained at $4^{\circ} \mathrm{C}$ after incubation for 48 to $72 \mathrm{~h}$ at $45^{\circ} \mathrm{C}$. TER/1 medium contained $20 \mathrm{~g}$ of crude maltose, $8 \mathrm{~g}$ of soya meal, $3 \mathrm{~g}$ of yeast extract (Difco Laboratories, Detroit, Mich.), and $20 \mathrm{~g}$ of agar in 1,000 $\mathrm{ml}$ of tap water $\left(\mathrm{pH} \mathrm{7)}\right.$; sterilization was done at $121^{\circ} \mathrm{C}$ for 30 $\min$.

Morphological characteristics. Morphological properties were determined by using 8 -h- to 3 -day-old cultures grown on TER $/ 1$ agar slants at $45^{\circ} \mathrm{C}$. Gram and spore staining was done as described by Salle (19).

Electron microscopy. Cells grown in broth culture were washed twice with a sterile physiological solution. One drop of the washed cell suspension was placed on a polyvinylFormvar-coated 300-mesh copper grid. Excess liquid was removed, and 1 drop of $2 \%$ phosphotungstic acid was added. The grid was allowed to air dry. Specimens were examined with a Siemens Elmiskop model $1 \mathrm{~A}$ electron microscope; photographs were taken on Afga Scientia plates.

Cultural and physiological characteristics. The media and procedures used for cultural and physiological characterizations were those described by Smith et al. (23), with some modifications. Unless otherwise indicated, the carbon sources used in the media were dissolved in distilled water and sterilized separately at $112^{\circ} \mathrm{C}$ for $30 \mathrm{~min}$, and all tests were performed at $45^{\circ} \mathrm{C}$ for different times ( 1 to 5 days). Growth was also assessed on malt agar, malt broth, potatoglucose-yeast extract agar and broth (3), skim milk, TER/1

\footnotetext{
* Corresponding author.
}

agar, TER/ 1 broth (at pH 5, 6, 7, and 8), and GYE agar and broth (containing $15 \mathrm{~g}$ of glucose, $5 \mathrm{~g}$ of yeast extract [Difco], and $0.2 \mathrm{~g}$ of $\mathrm{CaCl}_{2} \cdot 2 \mathrm{H}_{2} \mathrm{O}$ in $1,000 \mathrm{ml}$ of tap water, $\mathrm{pH} \mathrm{7).}$ The temperature range and optimum temperature for growth were determined on GYE agar and broth and on potatoglucose-yeast extract agar by observing growth at different temperatures in a variable-temperature incubator (Politermomatic-Rossi, Piacenza, Italy) (10). Basic nutrient requirements were determined by using the following media: SM medium [containing $3 \mathrm{~g}$ of $\left(\mathrm{NH}_{4}\right)_{2} \mathrm{SO}_{4}, 1 \mathrm{~g}$ of $\mathrm{KH}_{2} \mathrm{PO}_{4}$, $0.5 \mathrm{~g}$ of $\mathrm{MgSO}_{4} \cdot 7 \mathrm{H}_{2} \mathrm{O}, 0.1 \mathrm{~g}$ of $\mathrm{NaCl}$, and $0.1 \mathrm{~g}$ of $\mathrm{CaCl}_{2} \cdot 2 \mathrm{H}_{2} \mathrm{O}$ in $1,000 \mathrm{ml}$ of distilled water, $\mathrm{pH}$ 7], $\mathrm{SM}$ medium supplemented with $0.1 \mathrm{~g}$ of yeast extract per liter, and SM medium supplemented with vitamins $(100 \mu \mathrm{g}$ of biotin per liter, $400 \mu \mathrm{g}$ of calcium pantothenate per liter, 100 $\mu \mathrm{g}$ of folic acid per liter, $400 \mu \mathrm{g}$ of niacin per liter, $300 \mu \mathrm{g}$ of $p$-aminobenzoic acid per liter, $400 \mu \mathrm{g}$ of piridoxine hydrochloride per liter, $300 \mu \mathrm{g}$ of riboflavin per liter, and $400 \mu \mathrm{g}$ of thiamine hydrochloride per liter). Vitamin requirements were determined by the single-deletion technique (24).

Utilization of compounds as sole sources of carbon was determined by using SM medium lacking glucose but containing $0.1 \mathrm{~g}$ of yeast extract per liter. The test was performed by using sugars at concentrations of $0.5 \%$, alcohols or organic acids at concentrations of $0.2 \%$, and $0.01 \%$ phenol red as the indicator. The following substrates were used: $\mathrm{L}$-arabinose, D-cellobiose, D-fructose, D-galactose, Dglucose, glycerol, inositol, lactose, maltose, mannitol, mannose, D-melibiose, L-rhamnose, D-ribose, sorbitol, sucrose, trehalose, D-xylose, acetate, citrate, DL-lactate, L-malate, succinate, pyruvate, L-aspartate, and L-glutamate. The utilization of compounds as sole nitrogen sources was tested by using $\mathrm{SM}$ medium without $\left(\mathrm{NH}_{4}\right)_{2} \mathrm{SO}_{4}$ but containing $0.1 \mathrm{~g}$ of yeast extract per liter. The following nitrogen sources were tested: $\left(\mathrm{NH}_{4}\right)_{2} \mathrm{SO}_{4}(3 \mathrm{~g} /$ liter $), \mathrm{NaNO}_{3}$ (3 g/liter), urea (3 g/liter), tryptone (Difco) (1 g/liter), Neopeptone (Difco) (1 $\mathrm{g} /$ liter), and soytone (Difco) ( $1 \mathrm{~g} /$ liter). Inoculated minimal media without added carbohydrates or $\mathrm{N}$ sources were used as controls. All tests were performed in 100-ml Erlenmeyer flasks containing $10 \mathrm{ml}$ of medium. Each flask was inoculated with $0.1 \mathrm{ml}$ of inoculum grown at $45^{\circ} \mathrm{C}$ for $12 \mathrm{~h}$, incubated at $45^{\circ} \mathrm{C}$ in an alternating shaker $(1004-\mathrm{cm}$ strokes per min), and examined after 24,48 , and $72 \mathrm{~h}$. Cell density was measured at $650 \mathrm{~nm}$ by using a Spectronic 20 spectrophotometer (Bausch \& Lomb, Inc., Rochester, N.Y.) immediately after inoculation and after incubation for different lengths of time. A wavelength of $650 \mathrm{~nm}$ was chosen because in the carbo- 


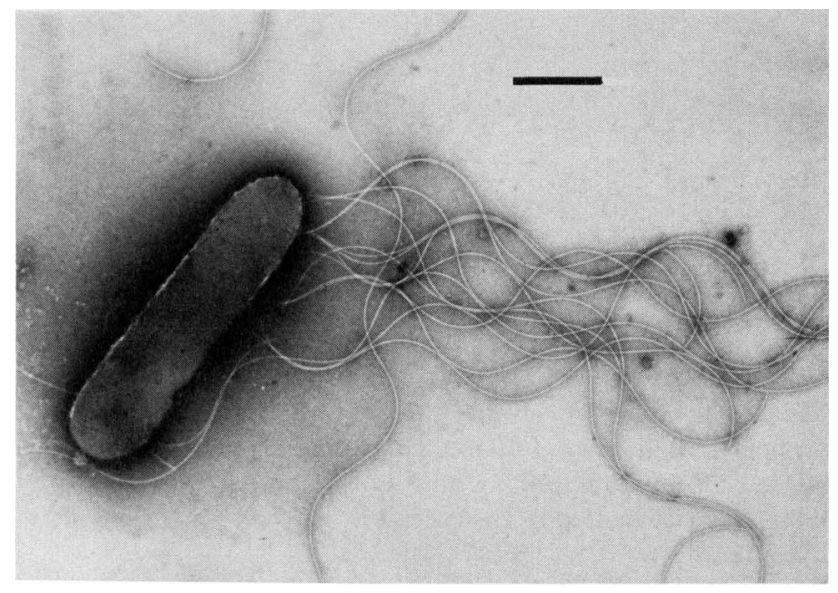

FIG. 1. Electron micrograph of Bacillus thermoruber strain $\mathrm{BT}^{\mathrm{T}}$. Bar $=1 \mu \mathrm{m}$.

hydrate test phenol red was used as the indicator. All tests were concluded after two subcultures on each medium.

Catalase production was determined by using cultures grown on TER/1 agar slants. The heat resistance of the spores was assessed by using a spore suspension in sterile 50 $\mathrm{mM}$ tris(hydroxymethyl) aminomethane ( $\mathrm{pH} 7)$ containing about $10^{8}$ spores per ml. After $20 \mathrm{~min}$ of incubation at different temperatures $(80,90,100,105,110,112,114$, and $\left.116^{\circ} \mathrm{C}\right), 1 \mathrm{ml}$ of the spore suspension was smeared on to TER/1 agar. Susceptibility to antibiotics was examined by using TER/1 agar and penicillin, tetracycline, vulcamycin, or chloramphenicol added at different concentrations. The results were recorded after $48 \mathrm{~h}$ of incubation at $40^{\circ} \mathrm{C}$.

Pigment extraction. The red pigment was extracted and characterized by the method of Guicciardi et al. (10), with a minor modification. The cells ( $30 \mathrm{~g}$, wet weight) were suspended in $50 \mathrm{ml}$ of distilled water containing $30 \mathrm{mg}$ of lysozyme (Boehringer, Mannheim, Federal Republic of Germany) and incubated at $37^{\circ} \mathrm{C}$ for $1 \mathrm{~h}$. The mixture was centrifuged at $48,000 \times g$ for $30 \mathrm{~min}$ at $4^{\circ} \mathrm{C}$, and the aqueous phase was removed. The pellet was washed with acetone, and the pigment was extracted several times with ethyl ether-ethanol $(1: 1, \mathrm{vol} / \mathrm{vol})$ containing $1 \%$ gaseous $\mathrm{HCl}$. Extracts were collected and evaporated, and the residue was dissolved in water and extracted with $n$-butanol. Crude pigment was purified by column chromatography on type MN300 cellulose (Macherei, Nägel \& Co., Düren, Federal Republic of Germany) as previously described (10).

Cellular fatty acid composition. Fatty acids analysis was performed by using the procedure of Aragozzini et al. (1). Strain $\mathrm{BT} 2^{\mathrm{T}}$ was grown for 4 days at $45^{\circ} \mathrm{C}$ on an alternating shaker (100 strokes per min) in medium containing $20 \mathrm{~g}$ of glucose, $2 \mathrm{~g}$ of yeast extract, and $0.5 \mathrm{~g}$ of $\mathrm{K}_{2} \mathrm{HPO}_{4}$ in $1,000 \mathrm{ml}$ of distilled water $(\mathrm{pH} 7)$. The cells were hydrolyzed by refluxing them under nitrogen for $4 \mathrm{~h}$ with $10 \% \mathrm{KOH}$ in $50 \%$ aqueous methanol; the fatty acids were extracted with hexane, and methyl esters were prepared by treatment with diazomethane. Fatty acid composition was determined by gas-liquid chromatography (Fractovap $\mathrm{G}_{1}$; Carlo Erba, Milan, Italy), using the following conditions: flame ionization detector; glass column ( $4 \mathrm{~mm}$ by $2.0 \mathrm{~m}$ ) containing $20 \%$ ethylene glycolsuccinate or $10 \%$ Apiezon $\mathrm{L}$ on Chromosorb W-LA (80-100 mesh) and kept at $190^{\circ} \mathrm{C}$; injector temperature, $270^{\circ} \mathrm{C}$; carrier gas, $\mathrm{N}_{2}$ at a flow rate of $40 \mathrm{ml} / \mathrm{min}$. Unsaturated fatty acids were separated by the method of
Goldfine and Bloch (8). Fatty acids were identified by comparing their retention times on each column with the retention times of standard methyl esters (Applied Science Div., Alltech Associates, Inc., State College, Pa.).

Determination of DNA base composition. Deoxyribonucleic acid (DNA) was extracted by the method of Marmur (15), with the minor modifications described by Dellaglio et al. (6) and Manachini and Parini (13). The final isopropanol DNA precipitate was dissolved in $0.1 \times$ standard saline citrate at a concentration of $20 \mu \mathrm{g} / \mathrm{ml}$, and the DNA base composition was determined by the thermal denaturation method (16), using a Beckman model ACTA-C-III spectrophotometer fitted with a circulating temperature bath. The guanine-pluscytosine $(\mathrm{G}+\mathrm{C})$ content of a DNA $\left(\mathrm{G}+\mathrm{C}_{\mathrm{x}}\right)$ was calculated from the following formula: $\mathrm{G}+\mathrm{C}_{\mathrm{x}}=\mathrm{G}+\mathrm{C}_{\mathrm{sTD}}+2.44\left(T_{m_{\mathrm{x}}}-\right.$ $T_{m_{\mathrm{sTD}}}$ ) (14), where $\mathrm{G}+\mathrm{C}_{\mathrm{sTD}}$ and $T_{m_{\mathrm{sTD}}}$ were the $\mathrm{G}+\mathrm{C}$ content and thermal denaturation midpoint temperature of the internal standard DNA, respectively, and $T_{m_{x}}$ was the thermal denaturation midpoint temperature of the DNA being investigated. The DNA of Escherichia coli strain B (Sigma Chemical Co., St. Louis, Mo.), which has a $\mathrm{G}+\mathrm{C}$ content of $50.9 \mathrm{~mol} \%$, was used as an internal standard.

\section{RESULTS}

Morphology. The cells of strain $\mathrm{BT} 2^{\mathrm{T}}$ were rod-shaped and 0.8 to 1.0 by 2.5 to $4.8 \mu \mathrm{m}$ and occurred singly and in short chains. The microorganism was gram positive; the endospores were oval $(0.9$ to 1.2 by 1.4 to $1.7 \mu \mathrm{m})$ and usually distended the sporangium in a terminal or subterminal position. Strain $\mathrm{BT} 2^{\mathrm{T}}$ was motile, and lateral flagella were visible by electron microscopy (Fig. 1). The colonies were circular, entire, convex, red pigmented, and smooth and had glossy and mucilaginous surfaces.

Cultural and physiological characteristics. Strain $B T 2^{\mathrm{T}}$ grows in skim milk with coagulation and peptonization. On TER/1 agar, GYE agar, and potato-glucose-yeast extract agar the growth is abundant, spreading, smooth, shiny, and red; in GYE broth strain $\mathrm{BT} 2^{\mathrm{T}}$ exhibits homogeneous turbid growth. The greatest intensity of pigmentation occurs during the stationary phase of growth, during the sporulation process. Growth is less intense on potato-glucose-yeast extract broth and glucose-asparagine agar. No growth is observed on SM medium; the addition of yeast extract $(0.1 \mathrm{~g} / \mathrm{liter})$ to SM medium allows growth. The yeast extract can be replaced with a vitamin solution; in particular, strain BT2 ${ }^{\mathrm{T}}$ requires either biotin or thiamine.

Strain $\mathrm{BT} 2^{\mathrm{T}}$ does not grow under anaerobic conditions. The temperature range for growth is 34 to $58^{\circ} \mathrm{C}$. Optimum growth occurs at 45 to $48^{\circ} \mathrm{C}$; no growth is observed at 30 or $65^{\circ} \mathrm{C}$.

Strain BT2 ${ }^{\mathrm{T}}$ does not synthesize acetylmethylcarbinol, indole, or hydrogen sulfide and does not produce catalase and tyrosine-degrading enzymes. No growth is produced in the presence of $5 \% \mathrm{NaCl}$; nitrate is not reduced to nitrite. Starch and casein are hydrolyzed, and gelatin is liquefied.

Strain $\mathrm{BT}^{\mathrm{T}}{ }^{\mathrm{T}}$ utilizes (without acid formation) L-arabinose, D-fructose, D-galactose, D-glucose, glycerol, inositol, maltose, mannitol, D-ribose, trehalose, and D-xylose. Citrate, L-malate, and pyruvate are not utilized. Utilization of acetate and succinate is weakly positive. Ammonium sulfate, urea, tryptone, soytone, and peptone are utilized as nitrogen sources, but $\mathrm{NaNO}_{3}$ is not.

Spores resist heating at $100^{\circ} \mathrm{C}$ for $20 \mathrm{~min}$, but do not survive at $112^{\circ} \mathrm{C}$.

Strain $\mathrm{BT} 2^{\mathrm{T}}$ does not grow in the presence of $5 \mu \mathrm{g}$ of penicillin per $\mathrm{ml}$ and $5 \mu \mathrm{g}$ of tetracycline per $\mathrm{ml}$; the 
inhibitory concentration of chloramphenicol and vulcamycin is $50 \mu \mathrm{g} / \mathrm{ml}$.

Red pigment. Strain $\mathrm{BT} 2^{\mathrm{T}}$ produces a red pigment on all media tested. The exact nature of this pigment has not been determined; a probable chinoid structure has been suggested (10). Elemental analysis gave the following results: $57.12 \%$ $\mathrm{C}, 6.28 \% \mathrm{H}$, and $3.40 \% \mathrm{~N}$. The pigment is soluble in methanol, ethanol, $n$-butanol, ethyl acetate and chloroform and insoluble in petroleum ether. When it was dissolved in methanol, the pigment showed a $\lambda_{\max }$ at $405 \mathrm{~nm}\left(E_{1 \mathrm{~cm}}^{1 \%}=680\right)$.

Cellular fatty acid composition. The total fatty acids obtained by alkaline hydrolysis represents 2 to $4 \%$ of the dry weight of strain BT2 $2^{\mathrm{T}}$ cells. A marked predominance of four branched-chain fatty acids is observed; iso- $\mathrm{C}_{15}$, anteiso- $\mathrm{C}_{15}$ iso- $\mathrm{C}_{17}$, and anteiso- $\mathrm{C}_{17}$ acids accounts for 80 to $90 \%$ of the total fatty acids. In particular, iso- $\mathrm{C}_{15}$ acid is consistently the most abundant fatty acid ( 44 to $60 \%$ ). The only unsaturated fatty acid present in very low amounts $(0.1$ to $3 \%)$ is $n-C_{18: 1}$ acid.

DNA base composition. The $\mathrm{G}+\mathrm{C}$ content of the DNA of strain $\mathrm{BT}^{\mathrm{T}}$ is $57 \pm 0.8 \mathrm{~mol} \%$.

\section{DISCUSSION}

The characteristics of strain $\mathrm{BT} 2^{\mathrm{T}}$ fit the description of the genus Bacillus as defined in Bergey's Manual of Determinative Bacteriology, 8th ed. (7). Moreover, the fatty acid composition of strain $\mathrm{BT} 2^{\mathrm{T}}$ is in agreement with the compositions reported for several species of Bacillus; specifically, it is like that of some thermophiles, such as Bacillus stearothermophilus, Bacillus caldolyticus, and Bacillus caldotenax $(12,17)$.

The previously described species of the genus Bacillus differ considerably from strain $\mathrm{BT}^{\mathrm{T}}$ in morphological, cultural, and physiological characteristics; furthermore, strain $\mathrm{BT}_{2}{ }^{\mathrm{T}}$ is easily distinguished from the other species by its peculiar red nondiffusible pigment. The base contents of the DNAs of members of the genus Bacillus are typically between 32 and $53 \mathrm{~mol} \% \mathrm{G}+\mathrm{C}(7,18)$; these values are lower than the value found for our isolate $(57 \mathrm{~mol} \% \mathrm{G}+\mathrm{C})$. Higher $\mathrm{G}+\mathrm{C}$ values have been found for the DNAs of some thermophilic species, including Bacillus thermocatenulatus (69 mol\%) (9), Bacillus schlegelii (67 to $68 \mathrm{~mol} \%$ ) (20), Bacillus caldovelox $(65$ mol\%) $(11,21)$, Bacillus caldotenax $(64.8 \mathrm{~mol} \%)(11,21)$, and Bacillus acidocaldarius $(61$ to 62 mol\%) (5). These differences suggest that strain $\mathrm{BT} 2^{\mathrm{T}}$ is not closely related to the previously described members of the genus Bacillus.

On the basis of the findings described above, we believe that strain $\mathrm{BT} 2^{\mathrm{T}}$ represents a new species of the genus Bacillus, for which we propose the name Bacillus thermoruber. A description of the new species is given below.

Bacillus thermoruber (ther'mo.ru.ber. Gr. n. therme heat; L. adj. ruber red; M.L. masc. adj. thermoruber heat loving and red pigment producing) cells are gram positive, straight rods 0.8 to 1.0 by 2.5 to $4.8 \mu \mathrm{m}$, with lateral flagellation; endospores are oval ( 0.9 to 1.2 by 1.4 to $1.7 \mu \mathrm{m})$ and terminal or subterminal and distinctly distend the sporangium. Colonies are red colored, circular, entire, and convex and have glossy and mucilaginous surfaces.

For growth, biotin or thiamine is required. L-Arabinose, D-fructose, D-galactose, D-glucose, glycerol, inositol, maltose, mannitol, D-ribose, trehalose, and D-xylose are utilized as sole carbon sources. Utilization of acetate and succinate is weakly positive. Ammonium sulfate, urea, tryptone, soytone, and peptone are utilized as nitrogen sources.
The temperature range for growth is 34 to $58^{\circ} \mathrm{C}$, and the optimum temperature is 45 to $48^{\circ} \mathrm{C}$. Positive physiological properties include gelatin liquefaction and starch and casein hydrolysis; negative properties include nitrate reduction, Voges-Proskauer reaction, indole production, tyrosine decomposition, hydrogen sulfide production, presence of catalase, and growth in the presence of $5 \% \mathrm{NaCl}$.

Iso- $\mathrm{C}_{15}$, anteiso- $\mathrm{C}_{15}$, iso- $\mathrm{C}_{17}$, and anteiso- $\mathrm{C}_{17}$ acids are the major cellular fatty acids.

The $\mathrm{G}+\mathrm{C}$ content of the DNA is $57 \pm 0.8 \mathrm{~mol} \%$.

Distribution: isolated from compost used for mushroom production.

The type strain is strain BT2, which has been deposited in the collection of the Cattedra di Microbiologia Industriale, Università di Milano, Milan, Italy, as strain MIM 30.8.38.

\section{LITERATURE CITED}

1. Aragozzini, F., P. Toppino, P. L. Manachini, and R. Craveri. 1976. Fatty acid composition of Bacillus thermoruber. Ann. Microbiol. (Milan) 26:9-13.

2. Craveri, R., A. Guicciardi, and N. Pacini. 1966. Distribution of thermophilic Actinomycetes in compost for mushroom production. Ann. Microbiol. (Milan) 16:111-113.

3. Craveri, R., P. L. Manachini, and F. Aragozzini. 1974. Thermostable and alkaline lipolytic and proteolytic enzymes produced by a thermophilic mold. Mycopathol. Mycol. Appl. 54:193-204.

4. Craveri, R., and H. Pagani. 1962. Thermophilic microorganisms among actinomycetes in the soil. Ann. Microbiol. (Milan) 12:115-124.

5. Darland, G., and T. D. Brock. 1971. Bacillus acidocaldarius sp. nov., an acidophilic thermophilic spore-forming bacterium. J. Gen. Microbiol. 67:9-15.

6. Dellaglio, F., V. Bottazzi, and L. D. Trovatelli. 1973. Deoxyribonucleic acid homology and base composition in some thermophilic lactobacilli. J. Gen. Microbiol. 74:289-297.

7. Gibson, T., and R. E. Gordon. 1974. Genus I. Bacillus Cohn 1872, p. 529-550. In R. E. Buchanan and N. E. Gibbons (ed.), Bergey's manual of determinative bacteriology, 8th ed. The Williams \& Wilkins Co., Baltimore.

8. Goldfine, H., and K. Bloch. 1961. On the origin of unsaturated fatty acids in clostridia. J. Biol. Chem. 236:2596-2601.

9. Golovacheva, R. S., L. G. Loginova, T. A. Salikhov, A. A. Kolesnikov, and G. N. Zaitseva. 1975. A new thermophilic species, Bacillus thermocatenulatus nov. sp. Mikrobiologiya 44:265-268.

10. Guicciardi, A., M. R. Biffi, P. L. Manachini, A. Craveri, C. Scolastico, B. Rindone, and R. Craveri. 1968. Ricerche preliminari su un nuovo schizomicete termofilo del genere Bacillus e caratterizzazione del pigmento rosso prodotto. Ann. Microbiol. (Milan) 18:191-205.

11. Heinen, U. J., and W. Heinen. 1972. Characteristics and properties of a caldoactive bacterium producing extracellular enzymes and two related strains. Arch. Mikrobiol. 82:1-23.

12. Kaneda, T. 1977. Fatty acids of the genus Bacillus: an example of branched-chain preference. Bacteriol. Rev. 41:391-418.

13. Manachini, P. L., and C. Parini. 1983. DNA restriction endonuclease cleavage patterns, DNA sequence similarity and phenotypical characteristics in some strains of Lactobacillus helveticus and Lactobacillus jugurti. Antonie van Leeuwenhoek J. Microbiol. Serol. 49:143-152.

14. Mandel, M., and J. Marmur. 1968. Use of ultraviolet absorbance-temperature profile for determining the guanine-pluscytosine content of DNA. Methods Enzymol. 12B:195-206.

15. Marmur, J. 1961. A procedure for the isolation of deoxyribonucleic acid from microorganisms. J. Mol. Biol. 3:208-218.

16. Marmur, J., and P. Doty. 1962. Determination of the base composition of deoxyribonucleic acid from its thermal denaturation temperature. J. Mol. Biol. 5:109-118.

17. Minnikin, D. E., and M. Goodfellow. 1981. Lipids in the classi- 
fication of Bacillus and related taxa, p. 59-90. In R. C. W. Berkeley and M. Goodfellow (ed.), The aerobic endosporeforming bacteria: classification and identification. Academic Press, Inc., London.

18. Priest, F. G. 1981. DNA homology in the genus Bacillus, p. 33-57. In R. C. W. Berkeley and M. Goodfellow (ed.), The aerobic endospore-forming bacteria: classification and identification. Academic Press, Inc., London.

19. Salle, A. Y. 1961. Laboratory manual on fundamental principles of bacteriology. McGraw-Hill Book Co., New York.

20. Schenk, A., and M. Aragno. 1979. Bacillus schlegelii, a new species of thermophilic, facultatively chemolithoautotrophic bacterium oxidizing molecular hydrogen. J. Gen. Microbiol.
115:333-341.

21. Sharp, R. J., K. J. Bown, and A. Atkinson. 1980. Phenotypic and genotypic characterization of some thermophilic species of Bacillus. J. Gen. Microbiol. 117:201-210.

22. Skerman, V. B. D., V. McGowan, and P. H. A. Sneath (ed.). 1980. Approved lists of bacterial names. Int. J. Syst. Bacteriol. 30:225-420.

23. Smith, N. R., R. E. Gordon, and F. E. Clark. 1952. Aerobic spore-forming bacteria. U.S. Department of Agriculture Monograph 16. U.S. Department of Agriculture, Washington, D.C.

24. Staley, J. T. 1968. Prosthecomicrobium and Ancalomicrobium: new prosthecate freshwater bacteria. J. Bacteriol. 95:19211942. 